\title{
Historic maps as a data source for socio-hydrology: a case study of the Lake Balaton wetland system, Hungary
}

\author{
A. Zlinszky ${ }^{1,2, *}$ and G. Timár ${ }^{3}$ \\ ${ }^{1}$ Balaton Limnological Institute, Centre for Ecological Research, Hungarian Academy of Sciences, Klebelsberg Kuno út 3 , \\ 8237 Tihany, Hungary \\ ${ }^{2}$ Department of Geodesy and Geoinformation, Vienna University of Technology, Gußhausstraße 27-29, 1040 Wien, Austria \\ ${ }^{3}$ Department of Geophysics and Space Science, Institute of Geography and Earth Sciences, Eötvös Loránd University, \\ Pázmány Péter Sétány 1/c, 1117 Budapest, Hungary
}

*Invited contribution by A. Zlinszky, recipient of the EGU Young Scientist Outstanding Poster Paper Award 2010.

Correspondence to: A. Zlinszky (andras.zlinszky@okologia.mta.hu)

Received: 1 June 2013 - Published in Hydrol. Earth Syst. Sci. Discuss.: 19 June 2013

Revised: 27 September 2013 - Accepted: 21 October 2013 - Published: 20 November 2013

\begin{abstract}
Socio-hydrology is the science of human influence on hydrology and the influence of the water cycle on human social systems. This newly emerging discipline inherently involves a historic perspective, often focusing on timescales of several centuries. While data on human history is typically available for this time frame, gathering information on the hydrological situation during such a period can prove difficult: measured hydrological data for such long periods are rare, while models and secondary data sets from geomorphology, pedology or archaeology are typically not accurate enough over such a short time. In the first part of this study, the use of historic maps in hydrology is reviewed. Major breakthroughs were the acceptance of historic map content as valid data, the use of preserved features for investigating situations earlier than the map, and the onset of digital georeferencing and data integration. Historic maps can be primary quantitative sources of hydro-geomorphological information, they can provide a context for point-based measurements over larger areas, and they can deliver time series for a better understanding of change scenarios.

In the second part, a case study is presented: water level fluctuations of Lake Balaton were reconstructed from maps, levelling logs and other documents. An 18th century map system of the whole $5700 \mathrm{~km}^{2}$ catchment was georeferenced, integrated with two 19th century map systems, and wetlands, forests and open water digitized. Changes in wetland area were compared with lake water level changes in a $220 \mathrm{yr}$ time
\end{abstract}

series. Historic maps show that the water level of the lake was closer to present-day levels than expected, and that wetland loss pre-dates drainage of the lake.

The present and future role of historic maps is discussed. Historic hydrological data has to be treated with caution: while it is possible to learn form the past, the assumption that future changes will be like past changes does not always hold. Nevertheless, old maps are relatively accessible data sets and the knowledge base for using them is rapidly growing, and it can be expected that long-term time series will be established by integrating georeferenced map systems over large areas.

In the Appendix, a step-by-step guide to using historic maps in hydrology is given, starting from finding a map, through georeferencing and processing the map to publication of the results.

\section{Introduction}

\subsection{What is socio-hydrology?}

Freshwater bodies are closely connected ecological, social and geomorphological systems (Wetzel, 2001), and on any timescale longer than a few decades, the approaches and methods of these disciplines have to be fused with hydrology for in-depth investigation of water resources (Sear and 
Arnell, 2006; Rice et al., 2010; Gilvear, 1999; James, 1999; Endreny, 2001; Widlok et al., 2012). From a human perspective, everyone has a right to safe drinking water and sanitation, and ensuring this under global climate change is a challenge for aquatic sciences (United Nations, 2010). From an ecological perspective, it is well known that the availability of water as a resource is one of the most important controlling factors of habitat development and succession (Gerten, 2013). From the point of view of hydrology, the quantity, quality and movement of water in the landscape has been the focus of scientific investigations since several centuries.

The demand to combine and integrate these views has been repeatedly addressed in science and also recognized by policy initiatives such as HELP (Hydrology for Environment, Life and Policy) by UNESCO (HELP Task Force, 2001) and the Water Framework Directive by the European Union (European Commission and European Parliament, 2000). The ever increasing human impact on the water cycle combined with the important role of water as a resource in forming human societies has led to the paradigm that the feedback between man and water, water and natural habitats, and natural habitats and man are each bidirectional. This is the framework of socio-environmental studies (Widlok et al., 2012).

Socio-hydrology deals with human influence on the water cycle and the influence of water availability and quality on human social systems (Sivapalan et al., 2012). In a world affected by global change and human population growth, it is not enough to understand the natural processes governing the water cycle, it is also essential to know the cultural reasons for people influencing aquatic systems (Gregory, 2006). Socio-hydrology is a context for decision support in order to ensure safe and sufficient access to clean water and protection from hydrological extremes (Di Baldassarre et al., 2013; Gober and Wheater, 2013). Governance with respect to hydrosystems increasingly requires a scientific background conscious not only of hydrological processes in natural systems but also past and future effects of human intervention (Yaeger et al., 2013). Socio-hydrology is a use-inspired, interdisciplinary field of study (Srinivasan et al., 2013; Srinivasan, 2013) with the urgency and the ethical background similar to other newly emerged fields of crisis science (conservation biology, global change research, disaster mitigation).

\subsection{Why bother with the past?}

Human pressure on aquatic systems is increasing, and informed decisions based on scientific facts are necessary to mitigate or optimize this process (Hoffmann et al., 2010). Interest in the past is part of various sciences dealing with aquatic systems for different reasons. Long-term processes are of inherent interest to "pure" science (such as history or palaeohydrology) as they are the frame for the short-term processes we perceive during a human lifetime. It is a gen- eral basis of scientific investigation that more data is better than less data, and therefore long-term records are often a perspective for expanding our knowledge (such as in ecology or hydrology). Finally, engineering and management changes aquatic environments, and these changes are mostly intended to last several human generations.

\subsubsection{Ecology and conservation}

Ecological processes often involve a lag in time, and recent studies have shown alarming evidence that the current local extinction risk of species depends more on socioeconomic pressures encountered a few decades ago than on the current rate of these pressures (Dullinger et al., 2013). This means that the negative (or positive) effect of current human activities will not be fully realized until several decades in the future. In order to gain a deeper understanding of the processes affecting our current natural capital (European Commission, 2011), historic human activities (and hydrological processes) have to be investigated.

Water regime is a major driver of ecological changes in lake systems (Coops et al., 2003). Especially changes in shore vegetation can not be understood without information on historic conditions on a timescale of centuries (Ostendorp, 1989). The Water Framework Directive allows member states to use palaeoecological or historic data to support the development of models of reference conditions for good ecological quality (European Commission and European Parliament, 2000).

Deliberate changing of aquatic system properties ("water management", aka. hydro-engineering) will have a profound effect on plant and animal communities (Gilvear, 1999), and while this is inherently difficult to study through controlled experiments, it is necessary to make predictions in order to conserve biodiversity despite (or through) river engineering (Rice et al., 2010). The other way round, vegetation is well known to influence shore erosion and sediment accumulation, which often means water management projects need to include the ecological engineering aspect.

\subsubsection{Hydro-engineering}

Humans have modified rivers, lakes and floodplain systems since ancient times, and continue to do so (Gregory, 2006; Iványi et al., 2012). Present-day aquatic systems management aims to broaden its scientific basis, because utilitarian and reductionistic water engineering has led to several problems (Sear and Arnell, 2006). Part of this scientific basis is the fusion of hydro-engineering and hydro-geomorphology (Gilvear, 1999; James, 1999) and also the acceptance of palaeohydrology as a science in its own right with implications for current water resource management (Gregory and Benito, 2003a; Sear and Arnell, 2006). A good estimate of future extreme events is necessary for river engineering, and palaeohydrological quantifications of such events can be 
used to assign rough probabilities to their recurrence in the future (Gregory and Benito, 2003b; Craciunescu et al., 2010).

In many cases, modern river management is difficult because little or no quantitative information exists on the natural sediment dynamics of the river before artificial modification. Many rivers in Europe were modified by humans centuries or millennia ago, so the original, natural status is impossible to quantify. Palaeohydrology works on the geological timescale (Baker, 2003), often struggling with higher temporal resolution investigations on the century scale due to the uncertainty of chronological constraints (Gregory and Benito, 2003b). However, advances in palaeohydrological dating methods have recently enabled proven chronological accuracies relevant for historic studies (Hobo et al., 2010; Appleby, 2008; Wallinga, 2002).

\subsubsection{Hydrology}

Taking a historic and process-based perspective when studying watershed processes is recommended for "pure" theoretical hydrological studies (Harman and Troch, 2013). Without information on historic changes, it might be assumed that the hydrological situation is static over time (James, 1999), while given information on earlier states of a watershed, the changes can be used to inform hydrological models (Yaeger et al., 2013).

However, palaeohydrological data is inherently sparse: fluvial or lake records dating back to more than a few decades are exceptionally rare (Baker, 2003). Other exploration methods suffer from the lack of spatial and temporal coverage, the uncertainty of interpretation, poor chronological constraints and the complexity of the processes investigated (Gregory and Benito, 2003b). Palaeohydrology is generally dealing with the period before any written records, as opposed to historic hydrology. Historic hydrology deals with the last few centuries in most cases and locations, and this is the period where human influence on aquatic systems rapidly increased. Changes that happened more closely in time to the present are more important for understanding the present situation (Gilvear, 1999), and therefore, historic hydrological processes are especially interesting for socio-hydrology (Srinivasan, 2013).

\subsubsection{Socio-hydrology}

Socio-hydrology relies heavily on understanding historical processes in order to learn how the present hydrological and social situation has been established, what the inherent fluctuation in the system is and how it has been dealt with (successfully or unsuccessfully) in the past (Yaeger et al., 2013; Srinivasan et al., 2012). In the typical case, historical sociohydrological investigations can be of quantitative nature as long as there are quantitative hydrological records available, and turns qualitative or model-based in the lack of these. History as a science in the humanity domain is rarely quantita- tive, and the accuracy and resolution of hydrological indicators such as palynology, geomorphology or pedology within a time frame of centuries is also limited. Therefore, a "data gap" exists in socio-hydrology, at the scale of centuries to decades. Historical information often lacks the direct accuracy of instrumental or experimental evidence. Many scientists and engineers are reluctant to use historical methods because the evidence may be anecdotal, incomplete and less quantifiable than records derived from recent instrumental measurements (James, 1999).

\subsection{Objective}

The objective of this study is to propose historic maps as a quantitative data source widely available for historical sociohydrology. The methods for processing historic spatial data in a quantitative and repeatable way are reviewed, together with applications in socio-(eco)-hydrology. A selected case study is presented in detail, where the aim is to revisit a wellestablished socio-hydrological concept on a major European Lake. Finally, a brief step-by-step guide for using historic maps in GIS (Geographical Information Systems) for sociohydrology is provided.

\subsection{The use of historic maps for hydrology: state of the art}

Water conditions of historic times can be estimated from historic documents, archaeology, abrasion forms, dendrochronology, sediment studies or palynology (Cholnoky, 1918; Bendefy and Nagy, 1969; Kern et al., 2009; Szanto and Medzihradszky, 2004; Zólyomi and Nagy, 1991; Cserny and Nagy-Bodor, 2000; Manville et al., 2007; Kremer, 2012; Lóczy, 1913). While these methods can provide representative and reliable data given certain circumstances, and are thus the mainstream methods of historic (or palaeo-) hydrology in general, their temporal resolution is rarely sufficient to represent the timescales typical for socio-hydrology, and their spatial coverage is often limited.

As uniform spatial models of the Earth's surface, maps provide area-wide representation of landscape features relevant to the time and purpose of surveying (Rumsey and Williams, 2002). Maps involve a defined scale and legend (otherwise it is not a map). Relying on the map scale, spatially accurate and quantitative analysis is possible. Based on the map legend, interpretation is straightforward and unambiguous as long as the map is preserved in good condition. These two properties (scale and legend) will determine maximum possible level of content detail, and the best theoretical spatial accuracy of data derived from a particular map. Most maps are in reality less detailed and accurate than this theoretical maximum, owing to interpolation between measurements and inaccurate observations of position or content.

During the early days of cartographic science, with the rapid evolution of geodesy, new maps were thought to be 
inherently better and more accurate than older maps, and historic maps were therefore not studied in detail. In the initial stage of historic map investigations, differences compared to the current situation were assessed by cartometric techniques and regarded as errors (Stegena, 1982; Cholnoky, 1918).

\subsubsection{Breakthrough 1: change detection instead of error detection}

Systematic studies of hydrological change based on historic maps probably began in the 1950s and 1960s, still including a critical approach to map content. An early monograph is the work of Bendefy (1969), summarizing the centennial changes in the shoreline of Lake Balaton through a detailed investigation of historic maps and documents. While spatial accuracy is practically not assessed in this book, comparable archaeological, geomorphological, sedimentological evidence together with written records and surveys are elaborately used for investigation of content accuracy.

During the 1970s and 1980s, image processing technology did not allow distortion of maps for georeferencing, and the correctness of historic map content was still not widely accepted. Nevertheless, quantitative studies were already possible (Klimek and Trafas, 1972; Sági, 1968; Braga and Gervasoni, 1989; Bravard et al., 1986). The book of Petts et al. (1989) provides an excellent overview of the state of the art of fluvial historic investigations before the onset of GIS georeferencing of historic maps. The uses for historic maps in river studies listed by this book are the following: qualitative uses can be change detection, classification of planform morphology, classification of types of change, dating and zoning of the floodplain. Possible quantitative investigations include measurement of channel or reach characteristics and meander characteristics (Petts, 1989).

The next major step was to finally move from an errordetection perspective to the working hypothesis that the surveyed content of a historic map is assumed to be correct. The result of this new approach is that even in cases where the map appears at first sight to show something impossible, it is worth investigating how it could have been correct at the time. The example of the Lazarus map (1528) illustrates this: first, the apparently incorrect northern direction of the map was resolved by realizing that it has the projection of Ptolemy (Timár et al., 2008a). The topography of major rivers was also assumed to be incorrect, but was proved correct or at least possible in the investigated cases (Székely, 2009). Finally, a lake of several hundred $\mathrm{km}^{2}$ shown on the map in a nowadays dry lowland was spectacularly traced by a major flood and thus confirmed (Timár et al., 2008b). Of course, the result of such an investigation is not always that all the features are correct. Depending on the context and intended use of the map in its own time, some features were surveyed more rigorously than others. In addition, areas inaccessible for surveying were typically drawn based on assumptions (Podobnikar, 2009).

\subsubsection{Breakthrough 2: some features can be a lot older than the map}

Historic maps may not only be used to draw consequences about the hydrological situation contemporary with the survey: they often contain signatures of situations in the earlier past, such as old river arms, vegetation boundaries or other features that allow even quantitative investigation (Large, 1996; Aston, 1985; Bravard, 2010). These might have been prominent during the time of the survey, but are mostly unrecognizable in the present-day landscape. On one hand, once such hydrological features are inactive, they are preserved in the landscape for thousands of years, which means historic maps can deliver information on a geological timescale (Timár et al., 2001, 2010b; Passmore and Macklin, 2000; Taylor and Lewin, 1996; Bondesan and Furlanetto, 2012; Popov et al., 2008). On the other hand, rivers react very sensitively to differential tectonic uplift, which can be analysed if historic maps show the original channels (Adams, 1980; Timár, 2003; Pišút, 2006; Zamolyi et al., 2010; Petrovszki and Timár, 2010; Kovács, 2010). Archaeological investigations have also benefitted from interpretation of prehistoric features on georeferenced historic maps (Sümegi, 2003; Toth, 2008; Raczky and Anders, 2009; Gyucha et al., 2011).

Maps have long been used as sources of information for long-term studies, but the possible accuracy of processing was often not considered sufficient for quantitative applications (Rumsey and Williams, 2002). Many very recent studies therefore still do not deal with spatial ground control of the maps they use, for various reasons: the survey can be considered accurate and consistent in itself (Bravard, 2010), the study might be of qualitative nature (Herget et al., 2005; Herget, 2000; Gercsák, 2009), or finding control points could be difficult (Pisut, 2002; Anthony and Blivi, 1999).

\subsubsection{Breakthrough 3: digital georeferencing, processing and distribution of historic maps}

During the last few decades, the implementation of projection transformation in GIS and the spread of digital aerial imaging have resulted in an increasing number of methodological studies concerning georeferencing of remotely sensed data. A deeper understanding of historic cartography and the migration of remote sensing processing technology to commercial GIS software has led to new, digital methods for transforming scanned historic maps (Leys and Werritty, 1999; Molnár, 2010), eventually even implemented in free software (Armas et al., 2013). Probably the work of Mossa and McLean (1997) is the first to describe a full workflow for georeferencing, digitizing and statistical evaluation of historic maps in a GIS environment. Systematic distortions of the map sheet (caused by miscalculations, shrinking of the paper, unknown geodetic basis) were corrected, while local (random) errors were preserved, as a measure of accuracy or a basis for change detection. This was 
a revolutionary step in the use of historic maps. Much better time series overlays could be produced, and maps compiled before the era of triangulation-based surveying from astronomical geodesy could also be georeferenced, some with surprising accuracy. This meant that historic data excluded from earlier studies were now included, effectively broadening the possible time frame by several centuries. Smallscale maps covering entire nations could also be studied together with more precise 18-19th century country maps, which was an advantage especially in areas where a long series of maps was conserved (Braga and Gervasoni, 1989; Pettersen, 2009; Bravard, 1989; Bruna et al., 2010; Krejci and Cajthaml, 2009).

Another major step enabled by GIS technology was the spatially explicit comparison with data gained from other sources, allowing verification (Pasternack et al., 2001) and more accurate timing (Timár and Gábris, 2008). Correlations in time and space have been searched in socio-hydrological studies of historic delta evolution (Fouache et al., 2001; Jabaloy-Sanchez et al., 2010; Sabatier et al., 2009; Longhitano and Colella, 2007; Tiron, 2010). The integration of historic map derived land use data with hydrological models allowed conclusions on the effect of social changes on aquatic systems even in cases where no deliberate modification of the water body by aquatic engineering has taken place. Some notable examples describe the variation in sediment load of waters in relation to historic land use change (Szilassi et al., 2006; Zlinszky et al., 2008).

Quantitative measures of river discharge and dynamics can be obtained from digitized channel outlines of meandering or braided rivers. Some of these studies remain in the geomorphology domain (Petrovszki et al., 2012; Petrovszki and Timár, 2010; Timár, 2003; Szabó et al., 2004; Timár et al., 2001), but cases exist where human influence is taken into account (Comiti et al., 2011; Ziliani and Surian, 2012; Kiss et al., 2008) or water resource management is the question in focus (Timár and Gábris, 2008; Craciunescu et al., 2010; Day et al., 1990; Zlinszky and Molnár, 2008, 2009). Based on the interpretation of historic maps, ecological changes caused by human interventions in river and lake systems can also be quantified (Bravard et al., 1986; Dömötörfy et al., 2003; Comiti et al., 2011; Gimmi et al., 2011).

The final step was web distribution: databases now allow rapid search and identification of historical geospatial information (Márton and Gede, 2009; Rychtáŕ, 2012).

The state of the art is accurate georeferencing of maps of large areas and comparative integration of GIS data derived from multiple historic maps, together with quantitative investigations of other sources. As the following case study shows, this approach can change well-established paradigms.

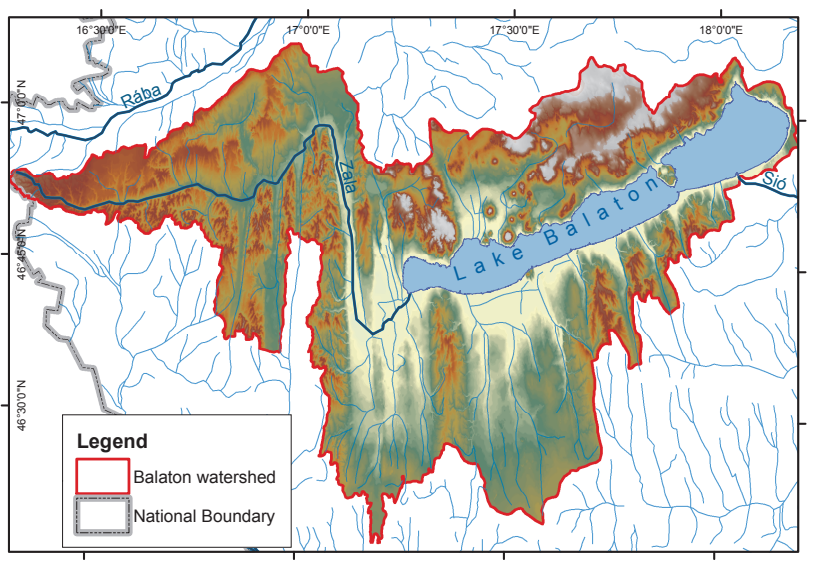

Fig. 1. Lake Balaton and the topography of its watershed. Elevation ranges between 100 and $500 \mathrm{~m}$ above sea level.

\section{Case study: historic water level fluctuations and wet-} land loss in the Lake Balaton catchment

\subsection{Study area: Lake Balaton}

\subsubsection{General description}

The largest lake in central Europe, Lake Balaton is located in western Hungary (Fig. 1). The lake has a surface area of $597 \mathrm{~km}^{2}$ at the current mean service water level, which is $105 \mathrm{~m}$ above sea level (a.s.l.) (throughout this case study, "sea level" refers to the Adriatic elevation benchmark). The eastern basin of the lake is drained by the Sió River to the Danube, and most of the tributaries enter the western basins. The long-term water balance of the lake is strongly controlled by evaporation, with annually approximately $900 \mathrm{~mm}$ of water evaporating from the surface, $600 \mathrm{~mm}$ drained through the outflow, $900 \mathrm{~mm}$ of water inflow from the tributaries and $600 \mathrm{~mm}$ of precipitation on the lake surface. The $5700 \mathrm{~km}^{2}$ catchment is located in a landscape of rolling hills to the west and south of the lake, and dolomite and volcanic mountains reaching $599 \mathrm{~m}$ a.s.l. to the north. Most valleys leading to the lake have gentle slopes and wide floors, and held large wetland systems in historic times.

On a geological timescale, Lake Balaton is a very young formation, existing since $15000 \mathrm{YBP}$ as separate sub-basins with a maximum water level of $112 \mathrm{~m}$ a.s.l. (Cserny and Nagy-Bodor, 2000) but permanently joined since 50007000 YBP (Sümegi et al., 2008). Several hypotheses exist for the formation of the lake, detailed especially in Horváth and Dombrádi (2010), but the general view is that the lake was formed by neotectonic processes changing the previously established drainage network and creating a series of depressions (Síkhegyi, 2002; Fodor et al., 2005). The strong seicheand wave-induced abrasion, which occurred during the periods when these were joined, eroded the ridges between the sub-basins and finalized their connection. The area still 
shows considerable tectonic activity (Gráczer et al., 2012) and differential uplift (Bendefy, 1964; Joó, 1992).

\subsection{Socio-hydrology of Lake Balaton}

The establishment of a single permanent lake basin instead of the periodically connected sub-basins is dated to the late $\mathrm{Ne}$ olithic, so human presence in the area actually pre-dates the formation of Lake Balaton in its current state. In historic documents, there are many discussed cases of artificial manipulations of the water level (Bendefy and Nagy, 1969; Virág, 1998, 2005).

Records from the last few centuries suggest at least $1 \mathrm{~m}$ of annual water level fluctuation, and $2-3 \mathrm{~m}$ on a decadal scale. According to archaeological evidence, the mean water levels were relatively close to the present-day situation throughout history, controlled by the sandbank across the outlet of the Sió river, which probably resulted in periodic floods and outflow events (Virág, 1998).

During the 18th century, the idea of draining Lake Balaton was raised together with the plan to link the agricultural areas of the Hungarian Plain to the grain market in the city of Graz by means of shipping canals (Bendefy and Nagy, 1969). However, this was not realized due to financial reasons for more than a century. The railway line along the southern shore was built during an extremely dry period in the mid-19th century. It was sited along the sandbar between the lake and the agricultural areas of the shore. The highest previously recorded water level was $106.73 \mathrm{~m}$ a.s.l., therefore the elevation of the railway tracks was fixed at $107.61 \mathrm{~m}$ and considered as a sufficient safety margin. However, during the winters of 1860-1861 and 1861-1862, blocks of ice were deposited on the tracks by storms. Regulating the water level was estimated to be cheaper than relocating the track, so the expansion of the Sió canal was funded by the railway company on the condition that the water of Lake Balaton had to be lowered by at least a meter. The sluice and lock system on the outflow of the Sió river from the lake was opened in 1863, introducing an artificial water regime of Lake Balaton (Meissner, 1867). This date also marks the beginning of regular water level recordings: a gauge was built and levelled as part of the shore protection walls near the outflow. After opening the sluice, the water level of the lake decreased temporarily by about a meter, but returned to its previous elevation during the next decade.

\subsubsection{State of the art concerning Lake Balaton and wetland water levels}

Bendefy (1969) describes water levels around $110 \mathrm{~m}$ above sea level between the 13th and 18th century, based on investigations of historic maps, documents and archaeological data. This is a well-established concept in Hungarian hydrology and water management (Padisák, 2005). Such high water level would have been sufficient for the lake to flood most of its historic tributary wetlands completely, covering about $900 \mathrm{~km}^{2}$. This surface was calculated to approximately represent equilibrium between evaporation and inflow (Nováky, 2005). The theory that the tributary wetlands around the lake were lost to the artificial drainage of Balaton is also widely accepted: as the water level shifted from $110 \mathrm{~m}$ to $105 \mathrm{~m}$ the valleys are assumed to have ran dry and their wetlands are supposed to have been reduced (Molnár and Kutics, 2013; Padisák, 2005). This concept has widespread implications: one of the objectives of present-day water level management on Lake Balaton is to raise the water levels, while the protection of the historic tributary wetlands is deemed impossible due to the changed water level situation in the lake. In the following case study, this paradigm is investigated based on quantitative analysis of historic maps.

\section{Methods}

\subsection{Historic maps of Lake Balaton: contents and properties}

\subsubsection{Surveying and content of the Krieger map (1776)}

The earliest known complete survey focusing on Lake Balaton was carried out in the 1770s in the framework of the plan for draining the lake (Fig. 2). The surveyor, Sámuel Krieger used the methods of the newly established Austrian Military Academy of Gumpendorf: optical levelling, measuring table triangulation and astronomical geodesy (Bendefy, 1972). The most prominent landmarks were sighted with a telescope rule and marked on the draft of the map, with the details of the landscape filled in by free hand. The scale is 1:34560 and is based on the standard measurement units of the time and area: 500 viennese fathoms in the terrain were mapped to 1 viennese inch on the map sheet, with 1 viennese fathom corresponding to $1.89 \mathrm{~m}$. Krieger also described the lake in text (Krieger, 1776; Zlinszky and Molnár, 2009), including measured water discharges and mill dam heights on the tributaries, water level fluctuations, shore characteristics and agricultural land use. The map contains bathymetric lines that correspond to different drainage scenarios, together with the planned canal system.

\subsubsection{Surveying and content of the Habsburg Military Surveys}

The second half of the 18th century was also the time of the first countrywide large-scale surveys. This is explained on one side by the increased need for accurate terrain data for artillery and cavalry-based warfare, and on the other side by the possibility of creating map systems of accurately conjoined sheets due to the precision of triangulation and the representation of the Earth as a globe.

The First Habsburg Military Survey (Fig. 3) was initiated in 1763 (Jankó, 2007), and the surveying (continued over 


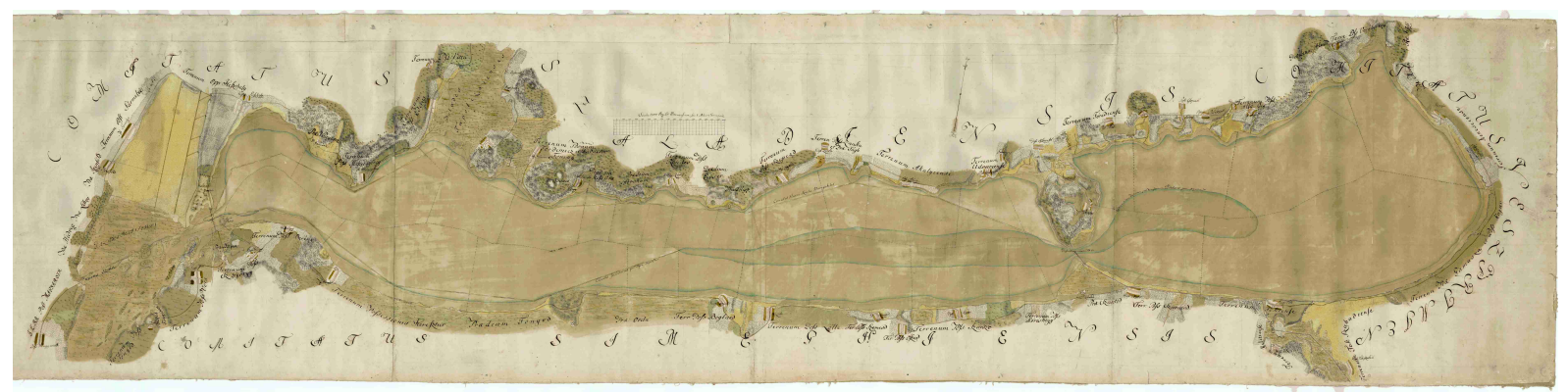

Fig. 2. Krieger's map of Lake Balaton (1776).

several decades) reached the Lake Balaton area around 1780. This map system is unique for its time in its coverage of six present-day countries with a mapping scale of 1:28 800, and is thus an invaluable source for environmental history and conservation. With details even including the size and shape of every single building, it demonstrates the state of the Austrian Empire before industrialization, modern agriculture or long-distance transport, an important benchmark for hydrology.

Wetlands, rivers and fords were of high military importance, and mapped to a considerable level of detail (Jankó, 2007). The individual sheets of the map were surveyed and drawn by different teams, using again measuring table and telescope rule triangulation for the major landmarks. While the map has no unified legend, the symbology of different sheets is rather similar and was resolved on the basis of the written documentation compiled during the survey (Dobai, 1983). According to the order of the Royal Military Council (Hofkriegsrat), these survey logs were required to contain "whether the swamps and wetlands can be traversed on horseback or foot, whether this is only possible in some seasons, or if they run dry regularly" (Jankó, 2007). Areas described as under shallow water the whole year round with vegetation covering the surface were considered wetlands for our study.

The Second Habsburg Military Survey (Fig. 3) was launched in the early 19th century, immediately after the first survey was finished, recognizing the evolution of mapping methods, especially cartographic projections (Hofstätter, 1989; Kretschmer et al., 2004; Timár et al., 2006). This map system was to have the same scale as the first, but supported by a well defined mathematical projection and a uniform map legend. Since surveying methods were faster with the onset of optical distance measurement, more triangulation points were surveyed and less detail added by hand. Around Lake Balaton, the survey was carried out in the 1830s, therefore providing a benchmark of the hydrological situation of the Lake before the regulation of the water level (Petts, 1989).

The Third Habsburg Military Survey (Fig. 3) was completed in the 1870s in the Lake Balaton region. This was the first mapping scheme to use the metric system, adjusting the scale to $1: 25000$. The representation of elevation with levelled contours and benchmark heights was introduced, and land cover classes were represented in more detail. Due to historical reasons, some of these map sheets are no longer available in their original coloured format, only in black and white print copies with letters representing the land cover categories.

\subsection{Processing of the maps to GIS data}

\subsubsection{Processing the Krieger Map and the lake water levels}

The scanning, georeferencing and processing of the Krieger map is described in detail by Zlinszky (2010). The water level was derived by comparing isobaths of the Krieger map with a digital bathymetric model of the lake. The water level calculated from the Krieger map was compared with other documented water level records of the period before the gauge was established. However, it was taken into account that different reconstruction methods produce different accuracies. The large number of points from bathymetric contour tracing allowed for statistical error assessment by comparing two independent point sets. In historical survey documents, some water level recordings exist that can be linked to present-day elevation systems (Meissner, 1867; Virág, 1998; Lotz, 1973; Sági, 1968). These were also considered accurate representations of historic water level, subject only to measurement error. Some previous authors also analysed other historic maps of the region and compared the shorelines with present-day elevation maps (Sági, 1968; Bendefy and Nagy, 1969). The results estimated with this method are less well established and often contradictory within periods or even single maps. Finally, some written records exist of extreme water levels being higher or lower than the water levels in other years (Virág, 1998, 2005). Since these are not based on documented measurements, they have to be treated with caution. 

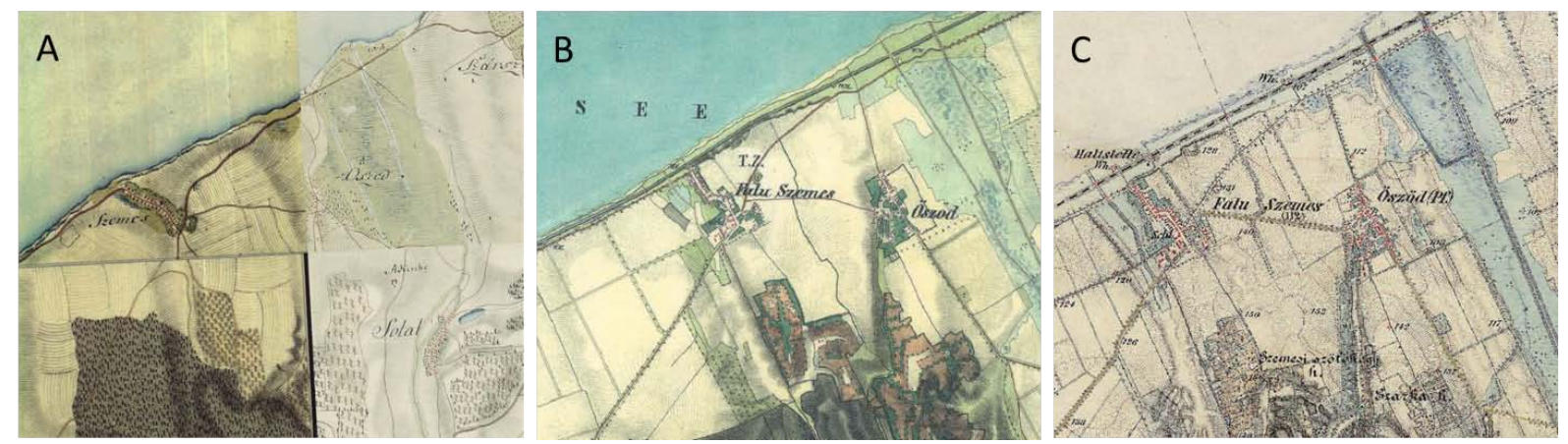

Fig. 3. Cutouts of the same area in the First (a), Second (b) and Third (c) Habsburg military surveys.

\subsubsection{Georeferencing of the First Military Survey}

Paper originals of the Military survey maps are preserved at the Austrian Military Archives (Kriegsarchiv), but have been scanned and are commercially available on DVD (Timár et al., 2006, 2010a; Timár and Molnár, 2006; Biszak et al., 2007). The map sheets of the First Military Survey probably have a Cassini projection with the tie point near the origin of the current Hungarian mapping system, but since no written evidence of this is known, it was decided to georeference them individually. The fit of the sheet edges creates a problem for georeferencing: if they were stitched to a single image, low-order polynomial transformations would not produce sufficient fitting accuracies. High-order transformations or triangulation (also known as "rubbersheeting") will not allow identification of incorrect control points and generally lead to overfitting. If, however, the map sheets are georeferenced separately with different low-order functions, the georeferenced sheets will not fit together at the edges. This was solved by applying the method of Molnár (2010), which allows individual third order polynomial transformation functions for every map sheet, but introduces and enforces a mathematical constraint that the edges must fit.

In order to gain seamless coverage of the whole Lake Balaton watershed $\left(5700 \mathrm{~km}^{2}\right), 51$ map sheets were georeferenced, each with a minimum of 10 ground control points. Corners of buildings were preferred as such points since they can be accurately localized in space provided that the building was unchanged. The Hungarian Art Memorial crowdsourcing database www.muemlekem.hu (Kunszt and Kovács, 2012) was used as a register: almost any building originating from the 18th century is officially protected and listed. The database was queried for each settlement in the study area, the buildings located by street address, and the coordinates read from a current 1:10000 scale digital topographic map of Hungary. After this step, the corresponding point of the Military Survey map sheet was also located, the transformation function calculated, and the map image warped. Reports from the more than 500 control points involved show an av- erage RMS (root mean square) error of $140 \mathrm{~m}$ (SD $131 \mathrm{~m}$ min $3 \mathrm{~m}$ max. $708 \mathrm{~m}$ ),

The second and third Military survey were compiled based on a regular mathematical projection with known details (Jankó, 2007), however the geodetic datum of the third survey has significant internal distortion because of the incomplete adjustment (Molnár and Timár, 2009). These maps are commercially available in a georeferenced format, reprojected with correction of the internal distortion (Biszak et al., 2007). The catchment area of Lake Balaton was clipped from both of these maps and used for subsequent processing.

\subsubsection{Digitizing of the Habsburg Military Survey maps and data analysis}

On the georeferenced First, Second and Third Military Survey map sheets, the boundaries of all open water surfaces, forests and wetlands were digitized for the whole catchment of Lake Balaton at an on-screen scale of 1: 20000. As a by-product of this, the 18th century elevation profiles of the water level in each tributary wetland were examined in detail (Zlinszky, 2010). Minor errors of the digitized boundary position and fit of coincident edges were corrected using the topology module of the open source GIS software GRASS. As a basis for comparison, the summed present-day area of the wetlands in the watershed was calculated from the CORINE land cover 2000 database (European Environmental Agency, 2000). In the final stage, changes in wetland area were compared with the water levels reconstructed from the Krieger map, other literature and the water gauge records.

\section{Results}

\subsection{Revisited water levels of Lake Balaton}

Based on measurements from the Krieger map and data published in the literature, the water level trends of Lake Balaton during the last $260 \mathrm{yr}$ were reconstructed (Fig. 4). The preregulation data can be regarded as a document of the natural water regime of the lake, not forgetting the fact that this is 
already influenced by human land use. Water levels fluctuated around $106 \mathrm{~m}$ a.s.l. ( $1 \mathrm{~m}$ above the current lake surface), while the earliest confirmed water level (Zlinszky, 2010) is at $107 \mathrm{~m}$. For several decades after 1776, no reconstructions are available, and the water level estimations preceding 1776 are rather uncertain as they are from manual measurements of non-georeferenced maps (Sági, 1968). The confirmed lake levels for the early 19 th century have a range of $2.3 \mathrm{~m}$, which represents the decadal variation, while according to a contemporary written description by a surveying hydroengineer (Krieger, 1776), the annual fluctuation could reach $1.2 \mathrm{~m}$.

Unfortunately, the water levels of the decades before the opening of the outlet canal are poorly documented, with most estimates based on manual comparison of historic maps with elevation contours. A transition from a mean of $106 \mathrm{~m}$ a.s.1. to $105 \mathrm{~m}$ can be followed in these data. The heights in the years immediately preceding the opening of the sluice are derived from levellings of Meissner (1867), linked to the Hungarian Geodetic Datum by Bendefy (1958). The regulated water levels of the lake initially show a decadal range of $1.6 \mathrm{~m}$ between $104.0 \mathrm{~m}$ a.s.1. in 1865 and $105.6 \mathrm{~m}$ in 1879 , implying that the water balance of the lake was not fundamentally influenced since the drainage capacity of the canal was only $10 \mathrm{~m}^{3} \mathrm{~s}^{-1}$ (Meissner, 1867). During subsequent enlargements of the canal and changes in control strategy, the decadal fluctuations were reduced to $0.6 \mathrm{~m}$ (104.6 $\mathrm{m}$ a.s.l. in 2003 and 105.2 in 2010) while the mean water level was stabilized around $105 \mathrm{~m}$.

\subsection{Changes in wetland area}

Meanwhile, the area of wetlands on the watershed also showed transition and stabilization (Fig. 4). During the late 18th century, the extent of permanent wetlands (excluding open water and periodically flooded areas) on the Lake Balaton watershed was $361 \mathrm{~km}^{2}$. In this initial stage, three major wetlands existed on the area, north, south and west of the lake, and the tributary valleys held several smaller swamps. By the early 19th century, large parts of all three major wetlands had been lost, with the total area reduced to $217 \mathrm{~km}^{2}$. Major wetlands lost especially their upstream reaches. During the next decades, some areas were lost, but others regained, especially in the northern and western valleys (though in this latter case at the expense of open water). The sum of $186 \mathrm{~km}^{2}$ shows minor losses compared to the previous period.

Finally, at the turn of the 20th and 21st century, the area of the wetlands was $130 \mathrm{~km}^{2}$. Most of this final major loss resulted from the drainage of large parts of the southern wetland area and the flooding of parts of the western wetland system, while some minor swamps were converted to fishponds. Some gains were also made: drainage was abandoned in most reed areas west of the lake.

At the first glance, this time series shows close connections with the changes in the water level of the lake (Fig. 4).
However, it is not to be overlooked that the most striking decrease in wetland area happened when there was no identified change in the lake water regime. $145 \mathrm{~km}^{2}$ of wetland area were lost on the watershed before the very first attempt to regulate Lake Balaton. The causes of these losses are disputed: climatic effects may have played a role, but the most important factor was probably the deliberate drainage of the wetlands themselves to clear land for agriculture. Comparing the wetland maps before and after the lake water level was lowered (Second and Third Military Survey), it is again clear that most of the wetland loss is not in the areas immediately adjacent to the lake. Some small patches were probably lost to the lessening demand for water mills and therefore the demolition of mill dams.

After 1870, during the intensification of agriculture and tourism, the Balaton region underwent a series of transitions. These included the canalization of some tributary streams with the intention of wetland drainage, especially on the northern and southern side. In the upstream part of the western (Kis-Balaton) wetland basin, the opposite process started with wetland reconstruction. With a system of dykes on the Zala River, a shallow pond of $18 \mathrm{~km}^{2}$ was created, in the hope that this will be encroached by wetland vegetation.

\section{Discussion}

\subsection{Implications of wetland and water level changes on Lake Balaton}

The earliest confirmed water level of the lake, from the year 1776, was published by Zlinszky (2010). This is only 2 meters above the current water level, and $3 \mathrm{~m}$ lower than indicated by previous authors (Bendefy and Nagy, 1969). Inconsistencies of map interpretation and fluctuations in water level may explain the previously established results (Virág, 1998), while contrary to these, the water level of the Krieger map is confirmed to represent an annual mean level (Virág, 2005).

Neither a comprehensive study of all wetlands on the watershed, nor spatially explicit time series investigations were undertaken on the whole Balaton watershed before this study. The ecological effect of the outlet canal was a continuous source of dispute ever since it was opened, so it is not surprising that it was often blamed for the process of wetland loss. Our study proved that tributary valley wetlands upstream of Lake Balaton are not directly dependent on the hydrological regime of the lake: most valleys have a well defined slope (Zlinszky, 2010). The aquatic vegetation had a water retention effect until the onset of artificial drainage. The combined water surface extent of the lake and wetland system could have been close to equilibrium of evaporation and inflow, without their water surfaces being at the same elevation. Nearly half of the wetland area on the watershed was lost before the demolition of the mill dam on the outlet of the 


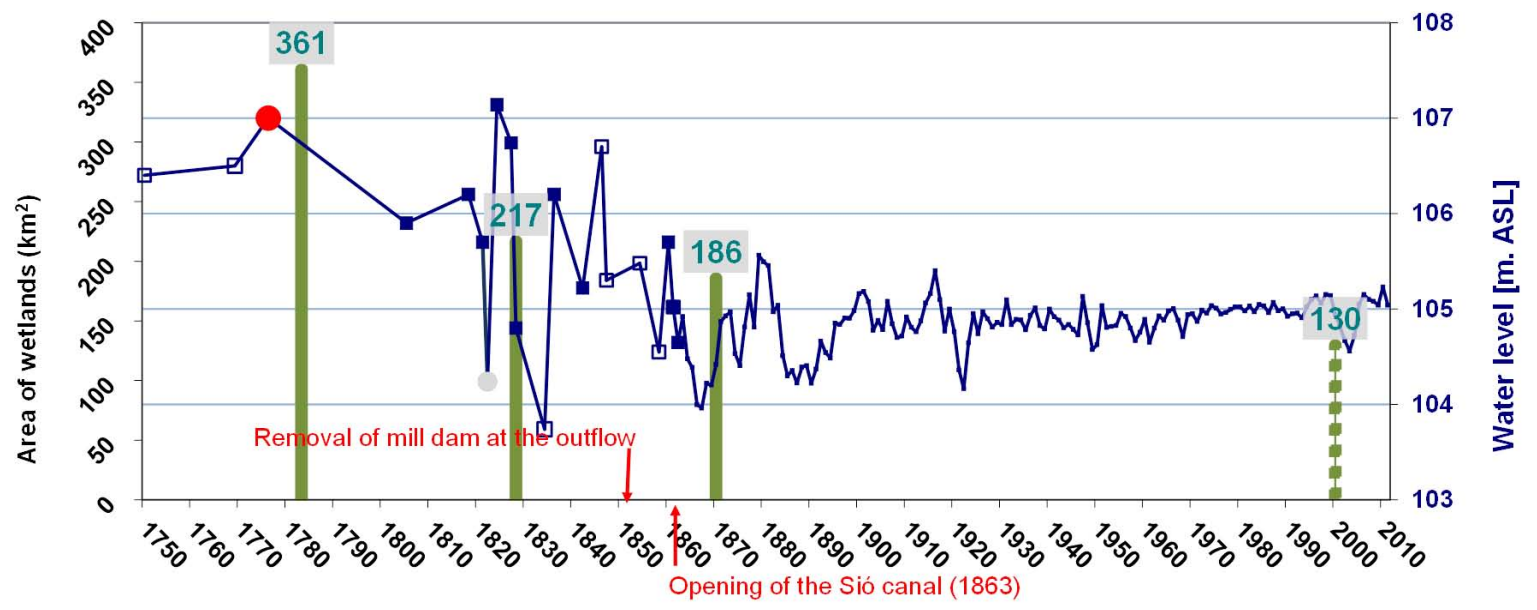

Wetland area - Water level - Reconstruction (levelling) Reconstruction (bathymetry) $\square$ Estimate (map) Estimate (written)

Fig. 4. Reconstructed, estimated and measured water levels of Lake Balaton and changes of wetland area through time on the Lake Balaton watershed.

lake (1848) which was the first engineering attempt to lower the water level. Some loss clearly happened parallel to the opening of the outlet canal, but this was already after the transition of the wetlands from their "original, natural" extents. In the light of the results, the previously accepted theory of wetland loss due to lake water level drop is improbable.

\subsection{Historic maps as a data source for socio-hydrological studies}

Historic data sets are a reliable source of information, but the past is not always a good guide to the future. We can not necessarily assume that change in the future will happen in the same way as it has in the past. We can seek evidence from periods in the past which can be used as analogues for future conditions and build scenarios which can be evaluated together with their probability. This is where palaeohydrology and historic socio-hydrology have a role (Sear and Arnell, 2006). According to James (1999), "historical methods should not replace quantitative scientific analyses but should be combined with them in a multi methodological approach to characterize fluvial systems".

\subsubsection{Time span}

One of the most important aspects of historic maps as a data source is the range of time they cover. Most such studies deal with 1-2 centuries, based on surveys with known mathematical and geodetic backgrounds (Ziliani and Surian, 2012; Craciunescu et al., 2010; Comiti et al., 2011; Bravard, 2010; Gimmi et al., 2011). In some countries where older cartographic records are also well preserved, it is possible to span 500 or even $800 \mathrm{yr}$, with spatial accuracies sufficient for quantitative analysis (Longhitano and Colella, 2007; Bondesan and Furlanetto, 2012; Timár et al., 2008b; Székely, 2009;
Armas et al., 2013; Kovács, 2010). This means that it is common for map-based historic hydrology studies to reach back in time to the Little Ice Age, which ended around 1850 A.D in Central Europe (Brown, 2003). The aim of long-term investigations is often to map the "original, undisturbed" state of a water body; in many cases this is impossible because human influence started before mapping. However, we have to state again that historic maps allow investigation of hydrological situations long before their time of surveying, if correctly interpreted (Timár and Gábris, 2008; Zamolyi et al., 2010; Aston, 1985; Large, 1996; Pisut, 2002). In extreme cases, several cycles of channel evolution or multiple stages of human intervention can be observed from long-term series (Longhitano and Colella, 2007; Braga and Gervasoni, 1989). Even in sites where the available map series only spans a few decades, valid conclusions can be derived, especially about anthropogenic processes (Mossa and McLean, 1997).

\subsubsection{Spatial accuracy and level of content detail}

One of the main reasons palaeohydrological data are rarely used in management contexts is their "uncertainty". This can be understood in terms of spatial position, timing of the situation represented in the survey, or correctness of the map content and its interpretation. Positional accuracy depends first and foremost on the accuracy and scale of the modern map used as "ground truth" for georeferencing. The scale of the historic original is also an important constraint, together with the random positional errors introduced by the mapping method. Scale, accuracy and map legend will determine whether a historic map can be of use for a certain purpose and resolution. Typical accuracies are around $200 \mathrm{~m}$ for 18th-19th century maps with scales around 1:25000 (Podobnikar, 2009; Zimova et al., 2006; Dömötörfy et al., 

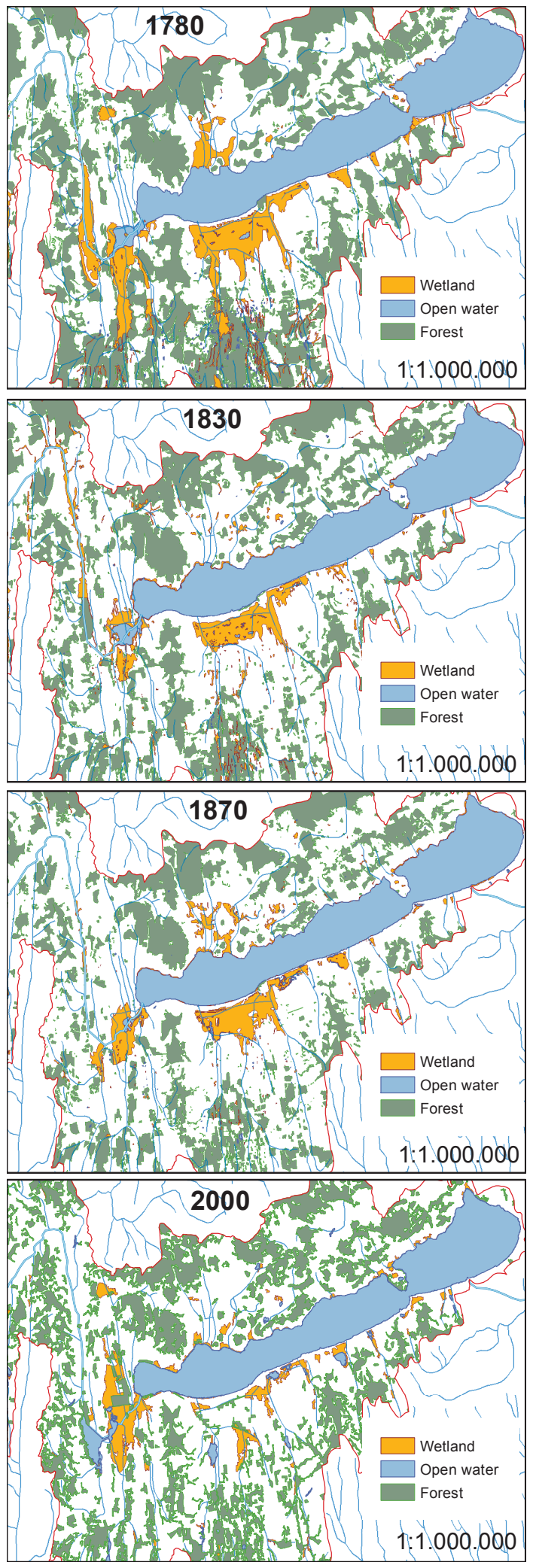

Fig. 5. Historic extents of wetlands, forests and open water on the Lake Balaton catchment.
2003), up to $5-10 \mathrm{~km}$ for older maps with scales around 1:1 000000 (Székely, 2009; Timár et al., 2008a). Fortunately, starting with the mid-19th century military topographic surveys, the original technology enables an absolute horizontal fitting better than $100 \mathrm{~m}$ (Timár et al., 2006; Molnár and Timár, 2009; Timár and Mugnier, 2010), while the local features (e.g. creek/river bends, gullies, shoreline details) have much better local accuracy (Feier and Rădoane, 2007; Timár, 2009). After WWI, the horizontal accuracy of most topographic maps was increased a lot: the absolute horizontal control is better than $10 \mathrm{~m}$ (Timár et al., 2004). Scale of the map itself limits the possible horizontal resolution; a rule of thumb is that half a millimetre on the original paper map is the physical limit of the horizontal control.

The timing of the situation depicted on a historic map is often quite certain, since the publication date of most maps is well established. However, this can be misleading: the surveys leading to a map may have taken place during a longer time, or the map can contain details copied from other maps. In most cases, historic data sets can be chronologically constrained within a few years even if not or incorrectly dated.

Finally, accuracy of the content interpreted depends on the map legend, the original level of surveying detail, and the quality in which the map was preserved. Most time series investigations define uniform categories for all studied maps (Ziliani and Surian, 2012), while others assign less categories to older maps (Comiti et al., 2011). The most rigorous method is to perform comparative analysis of map content with respect to other maps or data obtained by palaeohydrological methods, and categorize the map sources according to expected reliability (Bondesan and Furlanetto, 2012).

\subsubsection{The advantages of historic maps}

One of the advantages of historic maps over other palaeohydrological data sets is that the uncertainties of spatial, temporal and contextual correctness can be well quantified. Using ground control points, the georeferencing error can be assessed; based on map content, cartographic depiction and historic information, uncertainties in the time of the survey can be constrained, and based on the map legend and mapping process, at least some of the map content can usually be verified.

Remote sensing scientists are familiar with the trade-off between content accuracy, spatial accuracy and data coverage (Mather, 2006). While e.g. undisturbed sediment records can be pinpointed in time and space, they don't cover large areas; similarly historic text documents might give detailed descriptions of a landscape but are spatially inaccurate; historic maps typically cover large areas, represent snapshots of a given time, but their content is already a product of the cartographer's interpretation.

Palaeohydrological investigations based on dedicated proxy data can be costly (Sear and Arnell, 2006), while access to map archives is usually free of charge. With the 
commercialization of GIS technology, processing can also be very cost effective.

\subsubsection{Future prospects}

Specifically for socio-hydrology, two different research directions have been established: one is deriving hydrological information from the map, and data on human history from other sources. The other is the opposite, with human influence read from old maps, and hydrological processes represented with different proxies. The future is probably a combination of these, where spatial coverage of hydrological, ecological and human history data is obtained together from historic maps but verified by reference data from other methods.

Studies of locations where historic maps are abundant have shown that georeferencing and interpreting cartographic data creates a positive feedback on itself: as more georeferenced historic maps are available, it becomes easier to process and understand additional old maps of the region. The transfer of methodological knowledge to landscapes where fewer maps are available is also underway. In the near future, this could result in seamless coverage of large areas.

An Achilles' heel of local palaeohydrology and historic hydrology is the difficulty of distinguishing between natural variability and human influences, according to Gregory and Benito (2003a), since both act at the same place and time. This could at least partially be resolved by comparative analysis of a large number of relatively similar hydro-systems across a range of climatic and social conditions. Advanced hydrological, ecological and social data from historic maps with very wide spatial coverage can hopefully give rise to "comparative historic socio-hydrology".

\section{Conclusions}

Socio-hydrology deals with complex feedbacks between water, ecosystems and man, and relies on comparative case study analysis and historical investigations. Historic maps have been supporting these studies, especially since digital technology allowed accurate georeferencing and GIS integration. Comparison with external data can provide validation or information on causality.

In a case study, it has been shown that the coverage and accuracy of such data sets is sufficient to investigate water level and wetland changes on Lake Balaton in a historic sociohydrology context. Historic water levels were proven to have been closer to the current situation than previously assumed, and the independence of major wetland loss from changes in water regime of the lake downstream of them has been confirmed.

\section{Appendix A}

\section{Using historic maps for hydrology}

To our best knowledge, the latest guide to using historic maps for hydrology is Hooke and Redmond (1989), published before the era of digital map processing. In the following, we provide a short step-by-step manual for hydrologists with knowledge of GIS and intending to apply historic maps for socio-hydrology.

\section{A1 Where to start}

Once a studied site and time period is identified, familiarize yourself with the written history of the area. What were the major political systems and the important events linked to these? When were surveys of the area known to have been conducted?

Analyzing a certain study area, especially in western and central Europe, we can obtain more historical maps covering it, usually from different time intervals (Timár et al., 2007). Military action, the establishment of colonies, hydroengineering and transport works all needed their own surveys, and in most cases, these maps survive and are available in archives.

Spatial accuracy is a function of the technology used during the survey and drawing, together with the existence and adjustment of the geodetic network. How relevant the content and legend of historic maps might be for socio-hydrological studies will depend mainly on their original purpose. Hydrographic maps are probably the best for hydrological studies: they typically have large scale (in the cartographic sense) and fine detail, but might focus only on a single water body and thus have limited spatial coverage. They often ignore features considered irrelevant for hydrology such as land cover types or sometimes even human settlement. Any major hydro-engineering project (wetland drainage, levee building, canalization etc.) would require a baseline map of the original, un-engineered status of the site, which can provide invaluable sources of information on the natural situation before major human intervention. Since most such constructions were linked to the industrial revolution, the first hydrographic maps are typically from the 18th-19th century.

Military topographic maps are also highly valuable in most cases. Their relatively high scale is combined with the aim of full topographic representation to show all terrain details that are important for the military operations of their age. Prior to the end of the 19th century, such maps mostly serve the infantry, which means that waterways were accurately depicted as obstacles, ship transportation (crucial for supplies) and sources of water. Later, maps were mainly used for artillery purposes, which increased the need for accurate coordinate representation and also the depiction of relief (Jankó, 2007). The earliest such maps date to the expansion of military cartography in the mid-18th century. 
General country maps typically have smaller scale and thus less detail, they deliver a broader overview and only show major water bodies (Krejci and Cajthaml, 2009; Pettersen, 2009; Bartos-Elekes, 2010; Dumont and Debarbat, 1999). Their accuracy regarding small details is often a source of debate, but is sometimes well confirmed (Székely, 2009). In many cases, these are the oldest available maps (Bravard, 1989), and this is especially true for areas where the first preserved maps were compiled during exploration and colonization.

Cadastral maps are also spatially accurate, but since they focus on property, they are not physical but rather thematic maps (Petrovszki and Mészáros, 2010). While the direct representation of hydrologically relevant features may be limited, historic property boundaries are frequently linked to river channels, wetlands, or other natural boundaries. Therefore property maps can also outline such features centuries after the original water body has disappeared (Aston, 1985).

Already digitized historic maps might be available commercially or on the web, but the typical sources are historic, military or hydrographic archives. Work from regional level (typically national archives) to local level (archives only dealing with part of your site).

\section{A2 If a map is found}

If a map is available, familiarize yourself with the purpose of the mapping in detail. What is the intended use of these maps? Depending on that, what kind of features could have been especially emphasized or neglected? Search for descriptions, logs or memos created before or during the survey. Also other documents contemporary with the map could be a basis for checking content accuracy. Don't forget that the description might be available only in local language, or only in the scientific or political language of the period. In the lack of survey documentation, the first guess should be that there was no dedicated survey but most of the map was re-drawn based on earlier maps. This was and is a frequent practice, and definitely has to be checked before a map is used.

If the survey itself is confirmed but the method remains unknown, study the typical mapping methodology of the era and location. Historic textbooks of geodesy or cartography are available in libraries and provide a basis for this. What tools and calculations would have been used? What errors would result from these, and what accuracy can be expected? Does this fit the observations on the map? For example, are there any features mapped that do not serve the purpose of the map but may have been triangulation points? Is there any detailed record of the mapping projection used? If not, does the map itself provide a hint? The size of the map sheets, the starting point of the map section system or the position of map corners can be a basis for finding the right projection.

\section{A3 Scanning the map}

Is there a scan of the map available? If yes, what is the resolution and colour depth? Does this fit the planned scale of processing, is it relevant for the mapping itself? Typically, positions measured on paper maps have accuracies around $0.5 \mathrm{~mm}$, so typical scanning resolutions would be 300-400 dpi.

Maps should be scanned to a single data file for each physical sheet of paper. Always keep the frame and edge of the map, including any ornamental details, survey notes or the map legend, since they can prove useful for determining metadata. Use a lossless file format for this first stage in order to preserve the full content. If single-piece scanning is not available, it is also possible to stich a map together from parts scanned separately. A low-budget solution is to take a vertical axis photograph and correct for lens distortions, but this will necessarily compromise the final accuracy. It is usually worth scanning even a black and white print in colour, in order to distinguish stains and marks from the original map content.

If the map has a measured grid or a grid of meridians and parallels, the grid interval lengths can be checked digitally. This will give a good estimate of drawing accuracy and possible distortions of the paper map.

\section{A4 Georeferencing and reprojection}

If the map projection and its origin and parameters are known, it is possible to define the coordinate system in GIS software, locate certain coordinates on the map sheet based on its grid or frame, and then reproject in standard GIS software if necessary.

If the projection is unknown but several guesses exist, these can be tried and the accuracies of control points tested to give the most probable coordinate system (Timár et al., 2010c; Mészáros, 2012). If there is no information whether the map has a projection at all, the only way forward is to stitch all sheets together in image processing software, and georeference it as a whole sheet into the chosen coordinate system.

Finding control points is a crucial stage of georeferencing. The convex hull of the control points should cover the whole map sheet as far as possible, but points in the centre of the map area should also be included. The ideal case is if the map shows a network of benchmarked triangulation points which exist to the present day or can be identified in the reference data set. If certain buildings are unchanged between the historic survey and the GIS, this is also a source of precise control points. In the lack of these, road crossings or bridges can be expected to have been surveyed accurately. Property or administrative boundaries can also persist for centuries or more. Don't forget that some map symbols might be slightly shifted on the historic original map in order to allow easier drawing or interpretation. 
As a reference, a map system should be used that is as close in time and purpose to the historic map as possible, while sustaining the necessary accuracy. Bear in mind that artificial and also natural features could have changed, but marks of their earlier status might still be visible. Georeferenced aerial photos can also be a source of control points as long as they show ancient roads, villages or river channels. Field visits might be necessary to determine if a building or object could have possibly remained unchanged through longer time.

The method for transformation will have to depend on the number of control points available and their expected correctness. It is always necessary to use more than the mathematical minimum number of points a method requires, in order to check the error of the georeferencing. Polynomial warp functions deliver RMS accuracies of each ground control point. Triangulation, also known as rubbersheeting, produces fits with zero error, but accuracy can be checked with a leaveone-out approach. Depending on the original mapping system or technology, different methods could be useful: if the map does not have a mathematical coordinate system or projection, or if it is expected to have high random errors, these can be corrected by higher-order polynomial warp functions, but the lower RMS values resulting from this can be misleading. In this case, the neighbourhood of each control point can be considered fairly accurate. In the ideal case that the map has a sound coordinate system and is only expected to have minor systematic errors, a low-order transformation should be used in order to avoid overfitting.

\section{A5 Data preparation}

Once you have your map in a GIS, the same rules apply as to any map-derived GIS content. In the light of the information about the survey, try to interpret the map key from the scope of your research question. What features are you interested in and how are they represented in the map? In some cases, they are directly involved in the map symbology and are consistently marked. In other cases, you will have to create your own interpretation key to decide which features to digitize. Semi-automatic digitization based on image processing methods can be applied, since boundaries can typically be well recognized. The onscreen scale applied should be similar to the original drawing scale of the map, or slightly larger.

\section{A6 Calculation and evaluation}

The accuracy of the georeferencing process, and also the possible errors of map content interpretation will have an effect on the final accuracy of the data derived from the map. In an ideal case, data from several different surveys that overlap in time allow additional error assessments, but this is rare. Therefore, it is always a good idea to test the results against data obtained with other methods: do historic doc- uments confirm the results? Do any surviving signs in the present-day landscape support the identified features?

\section{A7 After completing the study}

If you have invested time in georeferencing and interpreting a historic map, it is good idea to share both the map and the resulting GIS data as long as data rights permit. Don't forget the metadata: all published results should include or at least refer to a discussion of the georeferencing method applied and the resulting positional accuracy. While the georeferenced data is your own work, the map you relied on is not. Making the results available to other users acknowledges the work of cartographers who created the original.

Acknowledgements. Present article was published in the frame of the project TÁMOP-4.2.2.A-11/1/KONV-2012-0064 "Regional effects of weather extremes resulting from climate change and potential mitigation measures in the coming decades". The project is realized with the support of the European Union, with the co-funding of the European Social Fund. AZ was funded by the Changehabitats2 Marie Curie IAPP Project. GT's work was supported by the Hungarian National Science Fund project OTKA NK-83400. Discussions with B. Székely and G. Molnár (ELTE Dept of Geophysics and Space Science) and the authors of the EGU 2008, 2009 and 2010 sessions "European cartographic heritage historical topographic maps and their application in environmental geosciences" have contributed substantially to the idea of this manuscript.

Edited by: G. Di Baldassarre

\section{References}

Adams, J.: Active tilting of the United States midcontinent Geodetic and geomorphic evidence, Geology, 8, 442-446, doi:10.1130/0091-7613(1980)8<442:ATOTUS > 2.0.CO, 1980.

Anthony, E. J. and Blivi, A. B.: Morphosedimentary evolution of a delta-sourced, drift-aligned sand barrier-lagoon complex, western Bight of Benin, Mar. Geol., 158, 161-176, doi:10.1016/s0025-3227(98)00170-4, 1999.

Appleby, P. G.: Three decades of dating recent sediments by fallout radionuclides: a review, Holocene, 18, 83-93, doi:10.1177/0959683607085598, 2008.

Armas, I., Nistoran, D. E. G., Osaci-Costache, G., and Brasoveanu, L.: Morpho-dynamic evolution patterns of Subcarpathian Prahova River (Romania), Catena, 100, 83-99, doi:10.1016/j.catena.2012.07.007, 2013.

Aston, M.: Interpreting the landscape - Landscape archaeology and local history, Taylor and Francis, London and New York, 1-165, 1985.

Baker, V.: Palaeofloods and extended discharge records, in: Palaeohydrology, Understanding global change, edited by: Gregory, K. J. and Benito, G., Wiley, Chichester, 2003.

Bartos-Elekes, Z.: Digital analyses concerning Honter's map, Acta Geoda. Geophys. Hu., 45, 3-8, doi:10.1556/AGeod.45.2010.1.2, 2010. 
Bendefy, L.: Szintezési munkálatok Magyarországon 1820-1920, Akadémiai Kiadó, Budapest, 736 pp., 1958.

Bendefy, L.: Geokinetic and crustal structure conditions of Hungary as recorded by repeated precision levelings, Acta Geol. Hu., 8, 395-411, 1964.

Bendefy, L. and Nagy, I.: A Balaton évszázados partvonalváltozásai, 1 ed., Múszaki Könyvkiadó, Budapest, 215 pp., 1969.

Bendefy, L.: Krieger Sámuel, Hidrológiai Tájékoztató, 11, 3-7, 1972.

Bondesan, A. and Furlanetto, P.: Artificial fluvial diversions in the mainland of the Lagoon of Venice during the 16th and 17th centuries inferred by historical cartography analysis, Geomorphologie, 2, 175-199, 2012.

Braga, G. and Gervasoni, S.: Evolution of the Po River, Italy an example of the application of historic maps, in: Historical changes of large alluvial rivers: Western Europe, edited by: Petts, G., Moeller, H., and Roux, A. L., Wiley, Chichester, 113-126, 1989.

Bravard, J.-P., Amoros, C., and Pautou, G.: Impact of civil engineering works on the successions of communities in a fluvial system - a methodological and predictive approach applied to a section of the upper Rhone river, France, Oikos, 47, 92-111, doi:10.2307/3565924, 1986.

Bravard, J.-P.: Cartography of rivers in France, in: Historical change of large alluvial rivers, Western Europe, edited by: Petts, G., Moeller, H., and Roux, A. L., Wiley, Chichester, 95-111, 1989.

Bravard, J.-P.: Discontinuities in braided patterns: The River Rhone from Geneva to the Camargue delta before river training, Geomorphology, 117, 219-233, doi:10.1016/j.geomorph.2009.01.020, 2010.

Brown, A. G.: Global environmental change and the Palaeohydrology of Western Europe: a review, in: Palaeohydrology: Understanding global change, edited by: Gregory, K. J. and Benito, G., Wiley, Chichester, 2003.

Bruna, V., Krovakova, K., and Nedbal, V.: Historical landscape structure in the spring area of the Blanice river, Southern Bohemia - An example of the importance of old maps, Acta Geod. Geophys. Hu., 45, 48-55, doi:10.1556/AGeod.45.2010.1.8, 2010.

Cholnoky, J.: A Balaton hidrográfiája, in: A Balaton tudományos tanulmányozásának eredményei, edited by: Lóczy, L., Franklin Társulat, Budapest, 1-318, 1918.

Comiti, F., Da Canal, M., Surian, N., Mao, L., Picco, L., and Lenzi, M. A.: Channel adjustments and vegetation cover dynamics in a large gravel bed river over the last 200 years, Geomorphology, 125, 147-159, doi:10.1016/j.geomorph.2010.09.011, 2011.

Coops, H., Beklioglu, M., and Crisman, T. L.: The role of water-level fluctuations in shallow lake ecosystems - workshop conclusions, Hydrobiologia, 506, 23-27, doi:10.1023/b:hydr.0000008595.14393.77, 2003.

Craciunescu, V., Flueraru, C., and Stancalie, G.: The usage of the historical cartographic datasets and the remote sensing data for the better understanding and mapping of the 2006 Danube floods in Romania, Acta Geod. Geophys. Hu., 45, 112-119, doi:10.1556/AGeod.45.2010.1.16, 2010.

Cserny, T. and Nagy-Bodor, E.: Limnogeology of Lake Balaton, Hungary, in: Lake basins through space and time, edited by: Gierlowski-Kordesch, E. H., and Kelts, K. R., AAPG Stud. Geol., 46, 605-618, 2000.
Day, R. H., Holz, R. K., and Day, J. W.: An inventory of wetland impoundments in the coastal zone of Louisiana, USA - Historical trends, Environ. Manag., 14, 229-240, 1990.

Di Baldassarre, G., Viglione, A., Carr, G., Kuil, L., Salinas, J. L., and Blöschl, G.: Socio-hydrology: conceptualising humanflood interactions, Hydrol. Earth Syst. Sci., 17, 3295-3303, doi:10.5194/hess-17-3295-2013, 2013.

Dobai, A.: Somogy Megye az Elsô katonai Felmérés (1782-1785) idején, Somogy megyei levéltár múltjából, 14, edited by: József, K., Somogy Megyei Levéltár, Kaposvár, 72 pp., 1983.

Dömötörfy, Z., Reeder, D., and Pomogyi, P.: Changes in the macrovegetation of the Kis-Balaton Wetlands over the last two centuries: a GIS perspective, Hydrobiologia, 506, 671-679, 2003.

Dullinger, S., Essl, F., Rabitsch, W., Erb, K.-H., Gingrich, S., Haberl, H., Hulber, K., Jarosik, V., Krausmann, F., Kuhn, I., Pergl, J., Pysek, P., and Hulme, P. E.: Europe's other debt crisis caused by the long legacy of future extinctions, P. Natl. Acad. Sci. USA, 110, 7342-7347, doi:10.1073/pnas.1216303110, 2013

Dumont, S. and Debarbat, S.: The academician astronomers travelling in the 18th century, Comptes Rendus De L'Academie Des Sciences Serie II., Fascicule B-Mecanique Physique Astronomie, 327, 415-429, 1999.

Endreny, T.: A global initiative for Hydro-Socio-Ecological watershed research, Water Resources Impact, 3, 20-25, 2001.

Feier, I. and Rădoane, M.: Dinamica în plan orizontal a Albiei Minore a râului Someşu Mic, înainte de lucrările hidrotehnice majore (1870-1968), Analele Universităţii "Ştefan cel Mare" Suceava, Secţiunea Geografie, 16, 5-22, 2007.

Fodor, L., Bada, G., Csillag, G., Horváth, E., Ruszkiczay-Rüdiger, Z., Palotás, K., Síhegyi, F., Timár, G., Cloetingh, S., and Horvath, F.: An outline of neotectonic structures and morphotectonics of the western and central Pannonian Basin, Tectonophysics, 410, $15-41,2005$

Fouache, E., Gruda, G., Mucaj, S., and Nikolli, P.: Recent geomorphological evolution of the deltas of the rivers Seman and Vjosa, Albania, Earth Surf. Proc. Land., 26, 793-802, doi:10.1002/esp.222, 2001.

Gercsák, G.: The first printed isobath map, Acta Geod. Geophys. Hu., 44, 17-26, doi:10.1556/AGeod.44.2009.1.3, 2009.

Gerten, D.: A vital link: water and vegetation in the Anthropocene, Hydrol. Earth Syst. Sci., 17, 3841-3852, doi:10.5194/hess-173841-2013, 2013.

Gilvear, D. J.: Fluvial geomorphology and river engineering: future roles utilizing a fluvial hydrosystems framework, Geomorphology, 31, 229-245, doi:10.1016/s0169-555x(99)00086-0, 1999.

Gimmi, U., Lachat, T., and Buergi, M.: Reconstructing the collapse of wetland networks in the Swiss lowlands 1850-2000, Landscape Ecol., 26, 1071-1083, doi:10.1007/s10980-011-9633-z, 2011.

Gober, P. and Wheater, H. S.: Socio-hydrology and the sciencepolicy interface: a case study of the Saskatchewan River Basin, Hydrol. Earth Syst. Sci. Discuss., 10, 6669-6693, doi:10.5194/hessd-10-6669-2013, 2013.

Gráczer, Z., Czifra, T., Kiszely, M., Mónus, P., and Zsíros, T.: Hungarian National Seismological Bulletin, Kövesligethy Radó Seismological Observatory, Budapest, 359 pp., 2012.

Gregory, K. J. and Benito, G.: Potential of palaeohydrology in relation to global change, in: Palaeohydrology: Understanding global 
change, edited by: Gregory, K. J., and Benito, G., Wiley, Chichester, 3-15, 2003a.

Gregory, K. J. and Benito, G.: Concluding perspective, in: Palaeohydrology: Understanding global change, edited by: Gregory, K. J., and Benito, G., Wiley, Chichester, 382-385, 2003 b.

Gregory, K. J.: The human role in changing river channels, Geomorphology, 79, 172-191, doi:10.1016/j.geomorph.2006.06.018, 2006.

Gyucha, A., Duffy, P. R., and Frolking, T. A.: The Körös Basin from the Neolithic to the Habsburgs: Linking Settlement Distributions with Pre-Regulation Hydrology Through Multiple Data Set Overlay, Geoarchaeology, 26, 392-419, doi:10.1002/gea.20350, 2011.

Harman, C. and Troch, P. A.: Darwinian hydrology: can the methodology Charles Darwin pioneered help hydrologic science?, Hydrol. Earth Syst. Sci. Discuss., 10, 6407-6444, doi:10.5194/hessd-10-6407-2013, 2013.

HELP Task Force: The design and implementation strategy of the HELP initiative, Technical documents in Hydrology, UNESCO, Paris, 62 pp., 2001.

Herget, J.: Holocene development of the River Lippe Valley, Germany: A case study of anthropogenic influence, Earth Surf. Proc. Land., 25, 293-305, doi:10.1002/(SICI)10969837(200003)25:3<293::AID-ESP63>3.0.CO;2-F, 2000.

Herget, J., Bremer, E., Coch, T., Dix, A., Eggenstein, G., and Ewald, K.: Engineering impact on river channels in the river Rhine catchment, Erdkunde, 59, 294-320, 2005.

Hobo, N., Makaske, B., Middelkoop, H., and Wallinga, J.: Reconstruction of floodplain sedimentation rates: a combination of methods to optimize estimates, Earth Surf. Proc. Land., 35, 1499-1515, doi:10.1002/esp.1986, 2010.

Hoffmann, T., Thorndycraft, V. R., Brown, A. G., Coulthard, T. J., Damnati, B., Kale, V. S., Middelkoop, H., Notebaert, B., and Walling, D. E.: Human impact on fluvial regimes and sediment flux during the Holocene: Review and future research agenda, Global Planet. Change, 72, 87-98, doi:10.1016/j.gloplacha.2010.04.008, 2010.

Hofstätter, E.: Beiträge zur Geschichte der österreichischen Landesaufnahmen, I. Teil, Bundesamt für Eich- und Vermessungswesen, Wien, 196 pp., 1989.

Hooke, J. M. and Redmond, C. E.: Use of cartographic sources for analysing river channel change with examples from Britain, U.K., in: Historical change of large alluvial rivers: Western Europe, edited by: Petts, G. E., Moeller, H., and Roux, A. L., Wiley, Chichester, 79-94, 1989.

Iványi, K., Kása, I., and Guti, G.: 3th IAD Conference - Living Danube - Proceedings, 3th IAD Conference - Living Danube, Szentendre, Hungary, 279-283, 2012.

Jabaloy-Sanchez, A., Jose Lobo, F., Azor, A., Barcenas, P., Miguel Fernandez-Salas, L., Diaz del Rio, V., and Vicente PerezPena, J.: Human-driven coastline changes in the Adra River deltaic system, southeast Spain, Geomorphology, 119, 9-22, doi:10.1016/j.geomorph.2010.02.004, 2010.

James, A.: Time and the persistence of alluvium: River engineering, fluvial geomorphology, and mining sediment in California, Geomorphology, 31, 265-290, doi:10.1016/s0169-555x(99)00084-7, 1999
Jankó, A.: Magyarország topográfiai felmérései 1763-1950, 1 ed., A Hadtörténeti Intézet és Múzeum Könyvtára, Argumentum Kiadó, Budapest, 2007.

Joó, I.: Recent vertical surface movements in the Carpathian Basin, Tectonophysics, 202, 129-134, 1992.

Kern, Z., Morgós, A., and Grynaeus, A.: Reconstructed precipitation for Southern Bakony Mountains (Transdanubia, Hungary) back to AD 1467 based on ring widths of oak trees, Időjárás, 113, 299-314, 2009.

Kiss, T., Fiala, K., and Sipos, G.: Alterations of channel parameters in response to river regulation works since 1840 on the Lower Tisza River (Hungary), Geomorphology, 98, 96-110, doi:10.1016/j.geomorph.2007.02.027, 2008.

Klimek, K. and Trafas, K.: Young-Holocene changes in the course of the Dunajec river in the Beskid Sadecki Mts. (Western Carpathians), Studia Geomorphologica Carpatho-Balcanica, 6, 85-90, 1972

Kovács, G.: The advantages of using the second military survey maps in fluvial studies, Acta Geod. Geophys. Hu., 45, 64-70, doi:10.1556/AGeod.45.2010.1.10, 2010.

Krejci, J. and Cajthaml, J.: Müller's maps of the Czech lands and their analysis, Acta Geod. Geophys. Hu., 44, 27-38, doi:10.1556/AGeod.44.2009.1.4, 2009.

Kremer, K.: Giant Lake Geneva tsunami in AD 563, Nat. Geosci. 5, 840-840, doi:10.1038/ngeo1656, 2012.

Kretschmer, I., Dörflinger, J., and Wawrik, F.: Österreichische Kartografie, Wiener Schriften zur Geographie und Regionalforschung, Institut für Geographie und Regionalforschung der Universität Wien, Wien, 318 pp., 2004.

Kunszt, G., Kovács, O.: www.muemlekem.hu, (last access: 14.06.2013), 2012.

Large, A. R. G.: Historical channel-floodplain dynamics along the River Trent, Appl. Geogr., 16, 191-209, 1996.

Lazarus (Secretarius): Tabula Hungariae ad quatuor latera. Eine kurze unnd warhafftige beschreibung des Ungerlands, Johannes Cuspinian, Ingostadt, 1528.

Leys, K. F. and Werritty, A.: River channel planform change: software for historical analysis, Geomorphology, 29, 107-120, doi:10.1016/s0169-555x(99)00009-4, 1999.

Lóczy, L.: A Balaton környékének geológiai képződményei és ezeknek vidékek szerinti telepedése, in: A Balaton tudományos tanulmányozásának eredményei, edited by: Lóczy, L., Franklin Társulat, Budapest, 1913.

Longhitano, S. and Colella, A.: Geomorphology, sedimentology and recent evolution of the anthropogenically modified Simeto River delta system (eastern Sicily, Italy), Sediment. Geol., 194, 195-221, doi:10.1016/j.sedgeo.2006.06.004, 2007.

Lotz, G.: A Balaton vízszintje a XIX. század elsô felében, Vízügyi Közlemények, 3, 337-341, 1973.

Manville, V., Hodgson, K. A., and Nairn, I. A.: A review of breakout floods from volcanogenic lakes in New Zealand, New Zeal. J. Geol. Geop., 50, 131-150, 2007.

Márton, M. and Gede, M.: Virtual Globes Museum: http://terkeptar. elte.hu/vgm/pubs.php?lang\$=\$en, (last access: 08.05.2013), 2009.

Mather, P. M.: Computer processing of remotely sensed images, John Wiley and Sons Ltd, Chichester, 324 pp., 2006.

Meissner, D. M.: Die Regulirung des Plattensees, Allgemeine Bauzeitung Wien, 27, 257-284, 1867. 
Mészáros, J.: The georeferencing method of the 1:5000 scale Danube maps, e-Perimetron, 7, 45-49, 2012.

Molnár, G. and Timár, G.: Mosaicking of the 1:75000 sheets of the Third Military Survey of the Habsburg Empire, Acta Geod. Geophys. Hu., 44, 115-120, doi:10.1556/AGeod.44.2009.1.11, 2009.

Molnár, G.: Making a georeferenced mosaic of historical map series using constrained polynomial fit, Acta Geod. Geophys. Hu., 45, 24-30, doi:10.1556/AGeod.45.2010.1.5, 2010.

Molnár, G. and Kutics, K.: Foreseen hydrological changes drive efforts to formulate water balance improvement measures as part of the management options of adaptation at Lake Balaton, Hungary, EGU General Assembly, Vienna, Austria, EGU201312296, 2013.

Mossa, J. and McLean, M.: Channel planform and land cover changes on a mined river floodplain, Appl. Geogr., 17, 43-54, 1997.

Nováky, B.: A Balaton vízpótlása és az éghajlat, Vízügyi Közlemények, 87, 105-123, 2005.

Ostendorp, W.: Dieback of reeds in Europe - a critical review of literature, Aquat. Bot., 35, 5-26, 1989.

Padisák, J.: Általános Limnológia, 1 ed., ELTE Eötvös Kiadó, Budapest, 1, 310 pp., 2005.

Passmore, D. G. and Macklin, M. G.: Late Holocene channel and floodplain development in a wandering gravel-bed river: The River South Tyne at Lambley, northern England, Earth Surface Processes and Landforms, 25, 1237-1256, doi:10.1002/10969837(200010)25:11<1237::AID-ESP134>3.0.CO;2-S, 2000.

Pasternack, G. B., Brush, G. S., and Hilgartner, W. B.: Impact of historic land-use change on sediment delivery to a Chesapeake Bay subestuarine delta, Earth Surf. Proc. Land., 26, 409-427, doi:10.1002/esp.189, 2001.

Petrovszki, J. and Mészáros, J.: The Great Hungarian Plain in the sheets of the Habsburg Military Surveys and some historical maps - A case study of the Körös/Cris drainage basin, Acta Geoda. Geophys. Hu., 45, 56-63, doi:10.1556/AGeod.45.2010.1.9, 2010.

Petrovszki, J. and Timár, G.: Channel sinuosity of the Körös River system, Hungary/Romania, as possible indicator of the neotectonic activity, Geomorphology, 122, 223-230, doi:10.1016/j.geomorph.2009.11.009, 2010.

Petrovszki, J., Székely, B., and Timár, G.: A systematic overview of the coincidences of river sinuosity changes and tectonically active structures in the Pannonian Basin, Global Planet. Change, 98, 109-121, doi:10.1016/j.gloplacha.2012.08.005, 2012.

Pettersen, B. R.: The first astro-geodetic reference frame in Norway 1779-1815, Acta Geod. Geophys. Hu., 44, 67-78, doi:10.1556/AGeod.44.2009.1.7, 2009.

Petts, G.: Historical analysis of fluvial hydrosystems, in: Historical changes of large alluvial rivers: Western Europe, edited by: Petts, G. E., Moeller, H., and Roux, A. L., Wiley, Chichester, 1-18, 1989.

Pišút, P.: Channel evolution of the pre-channelized Danube River in Bratislava, Slovakia (1712-1886), Earth Surf. Proc. Land., 27, 369-390, doi:10.1002/esp.333, 2002.

Pišút, P.: Evolution of the meandering Lower Morava River (West Slovakia) during the first half of the 20th century, Geomorphologica Slovaca, 6, 55-68, 2006.
Podobnikar, T.: Georeferencing and quality assessment of Josephine Survey maps for the mountainous region in the Triglav National Park, Acta Geod. Geophys. Hu., 44, 49-66, doi:10.1556/AGeod.44.2009.1.6, 2009.

Popov, D., Markovic, S. B., and Štrbac, D.: Generations of meanders in Serbian part of Tisa valley, Geographical Institute "Jovan Cvijic" Sasa collection of papers, 58, 29-42, 2008.

Raczky, P. and Anders, A.: Régészeti kutatások egy késô neolitikus településen - Polgár-Bosnyákdomb (Előzetes jelentés), Archaeológiai Èrtesítô, 134, 5-21, 2009.

Rice, S. P., Lancaster, J., and Kemp, P.: Experimentation at the interface of fluvial geomorphology, stream ecology and hydraulic engineering and the development of an effective, interdisciplinary river science, Earth Surf. Proc. Land., 35, 64-77, doi:10.1002/esp.1838, 2010.

Rumsey, D. and Williams, M.: Historical maps in GIS, in: Past Time, Past Place - GIS for History, 1 Edn., edited by: Knowles, A. K., ESRI Press, Redlands, CA, USA, 1-19, 2002.

Rychtář, J.:Moll's map collection: http://mapy.mzk.cz/en/, (last access: 08.05.2013), 2012.

Sabatier, F., Samat, O., Ullmann, A., and Suanez, S.: Connecting large-scale coastal behaviour with coastal management of the Rhone delta, Geomorphology, 107, 79-89, doi:10.1016/j.geomorph.2006.09.026, 2009.

Sági, K.: A Balaton vízállástendenciái 1863-ig a történeti és kartográfiai adatok tükrében, A Veszprém megyei múzeumok közleményei, 7, 441-468, 1968.

Sear, D. A. and Arnell, N. W.: The application of palaeohydrology in river management, Catena, 66, 169-183, doi:10.1016/j.catena.2005.11.009, 2006.

Síkhegyi, F.: Active structural evolution of the western and central parts of the Pannonian basin: a geomorphological approach, EGU Stephan Mueller Special Publication Series, 3, 203-216, 2002.

Sivapalan, M., Savenije, H. H. G., and Bloeschl, G.: Sociohydrology: A new science of people and water, Hydrol. Process., 26, 1270-1276, doi:10.1002/hyp.8426, 2012.

Srinivasan, V., Lambin, E. F., Gorelick, S. M., Thompson, B. H., and Rozelle, S.: The nature and causes of the global water crisis: Syndromes from a meta-analysis of coupled human-water studies, Water Resour. Res., 48, 1-15, doi:10.1029/2011wr011087, 2012.

Srinivasan, V.: Socio-hydrology: patterns, feedbacks, goals and trajectories in coupled human-water systems, Catchment Science Symposium, Vienna, Austria, 13 April 2013, 2013.

Srinivasan, V., Seto, K. C., Emerson, R., and Gorelick, S. M.: The impact of urbanization on water vulnerability: A coupled humanenvironment system approach for Chennai, India, Global Environ. Chang., 23, 229-239, doi:10.1016/j.gloenvcha.2012.10.002, 2013.

Stegena, L.: Distortions on Lazarus maps, in: Lazarus Secretarius The first Hungarian mapmaker and his work, edited by: Stegena, L., Akadémiai Kiadó, Budapest, 97-102, 1982.

Sümegi, P.: Early Neolithic man and riparian environment in the Carpathian Basin, in: Morgenrot der Kulturen, edited by: Jerem, E. and Raczky, P., Archaeolingua Press, Budapest, 53-60, 2003.

Sümegi, P., Gulyás, S., and Jakab, G.: Holocene paleoclimatic and paleohydrological changes in Lake Balaton as inferred from a complex quantitative environmental historical study of a lacus- 
trine sequence of the Szigliget embayment, Documenta Praehistorica, 35, 33-43, 2008.

Szabó, M., Timár, G., and Gyǒri, H.: A Csicsói-holtág (AlsóCsallóköz) kialakulása és fejlödése - a tájhasználat és a vizes élőhelytípusok változása, Tájökológiai Lapok, 2, 267-286, 2004.

Szanto, Z. and Medzihradszky, Z.: Holocene environmental changes in western Hungary, Radiocarbon, 46, 691-699, 2004.

Székely, B.: Rediscovering the old treasures of cartography - what an almost 500 year-old map can tell to a geoscientist, Acta Geod. Geophys. Hu., 44, 3-16, doi:10.1556/AGeod.44.2009.1.2, 2009.

Szilassi, P., Jordan, G., van Rompaey, A., and Csillag, G.: Impacts of historical land use changes on erosion and agricultural soil properties in the Kali Basin at Lake Balaton, Hungary, Catena, 68, 96-108, 2006.

Taylor, M. P. and Lewin, J.: River behaviour and Holocene alluviation: The River Severn at Welshpool, mid-Wales, UK, Earth Surf. Proc. Land., 21, 77-91, doi:10.1002/(SICI)10969837(199601)21:1<77::AID-ESP547>3.0.CO;2-O, 1996.

Timár, G., Sümegi, P., Geiger, J., Szántó, Z., and Bodor, E.: Story of an oxbow lake: An outlook to the Holocene tectonics and climate of the Great Hungarian Plain, in: EGS Stephan Mueller Topical Conference Series, Quantitative Neotectonics and seismic hazard assessment: New integrated approaches for environmental management, Balatonfüred, Hungary, 2001.

Timár, G.: Controls on channel sinuosity changes: a case study of the Tisza River, the Great Hungarian Plain, Quaternary Sci. Rev., 22, 2199-2207, doi:10.1016/s0277-3791(03)00145-8, 2003.

Timár, G., Lévai, P., Molnár, G., and Varga, J.: A második világháború német katonai térképeinek koordinátarendszere, Geodézia és Kartográfia, 56, 28-35, 2004.

Timár, G. and Gábris, G.: Estimation of water conductivity of the natural flood channels on the Tisza flood-plain, the Great Hungarian Plain, Geomorphology, 98, 250-261, doi:10.1016/j.geomorph.2006.12.031, 2008.

Timár, G., Molnár, G., Székely, B., and Plihál, K.: Lázár térképe és a ptolemaioszi vetület, Geodézia és Kartográfia, 60, 20-26, 2008a.

Timár, G., Székely, B., Molnár, G., Ferencz, C., Kern, A., Galambos, C., Gercsák, G., and Zentai, L.: Combination of historical maps and satellite images of the Banat region - Re-appearance of an old wetland area, Global Planet. Change, 62, 29-38, doi:10.1016/j.gloplacha.2007.11.002, 2008b

Timár, G.: System of the 1:28800 scale sheets of the Second Military Survey in Tirol and Salzburg, Acta Geod. Geophys. Hu., 44, 95-104, doi:10.1556/AGeod.44.2009.1.9, 2009.

Timár, G., Biszak, S., Székely, B., and Molnár, G.: Digitized maps of the Habsburg military surveys: overview of the projects of Arcanum Ltd. (Hungary), in: Preservation in digital cartography, edited by: Jobst, M., Lecture Notes in Geoinformation and Cartography, Springer, Berlin-Heidelberg, 273-283, 2010a.

Timár, G., Csillag, G., Székely, B., Molnár, G., Galambos, C., and Czanik, C.: A Balaton legnagyobb kiterjedésének rekonstrukciója a függőleges kéregmozgások figyelembevételével, Földtani Közlöny, 140, 455-462, 2010 b.

Timár, G., Molnár, G., Székely, B., and Plihál, K.: Orientation of the map of Lazarus (1528) of Hungary - result of the Ptolemian projection?, in: Cartography in Central and Eastern Europe, edited by: Gartner, G., and Ortag, F., Lecture Notes in Geoinformatics and Cartography, Springer, Berlin-Heidelberg, 487-496, 2010c.
Timár, G. and Mugnier, C. J.: Rectification of the Romanian $1: 75000$ map series, prior to World War I, Acta Geod. Geophys. Hu., 45, 89-96, doi:10.1556/AGeod.45.2010.1.13, 2010.

Tiron, L.: Delta du Danube - Bras de St. George/Mobilité morphologique et dynamique hydro-sedimentaire depuis 150 ans, Geo-Eco-Marina Publications, 4, 1-280, 2010.

Toth, A. J.: River archaeology - a new tool for historical hydrology, 24th Conference of The Danubian Countries on The Hydrological Forecasting and Hydrological Bases of Water Management, Bled, Slovenia, 1-8, 2008.

Virág, Á.: A Balaton Múltja és Jelene, 1 Edn., Egri nyomda, Eger, 904 pp., 1998

Virág, Á.: A Sió és a Balaton közös története, 1 Edn., Közlekedési Dokumentációs Kft., Budapest, 437 pp., 2005.

Wallinga, J.: Optically stimulated luminescence dating of fluvial deposits: a review, Boreas, 31, 303-322, 2002.

Wetzel, R., G: Limnology, 3 Edn., Academic Press, London, 1066 pp., 2001.

Widlok, T., Aufgebauer, A., Bradtmoeller, M., Dikau, R., Hoffmann, T., Kretschmer, I., Panagiotopoulos, K., Pastoors, A., Peters, R., Schaebitz, F., Schlummer, M., Solich, M., Wagner, B., Weniger, G.-C., and Zimmermann, A.: Towards a theoretical framework for analyzing integrated socio-environmental systems, Quatern. Int., 274, 259-272, doi:10.1016/j.quaint.2012.01.020, 2012.

Yaeger, M. A., Sivapalan, M., McIsaac, G. F., and Cai, X.: Comparative analysis fo hydrologic signatures in two agricultural watersheds in east-central Illinois: legacies of the past to inform the future, Hydrol. Earth Sys. Sci. Discuss., 10, 6515-6558, doi:10.5194/hessd-10-6515-2013, 2013.

Zamolyi, A., Szekely, B., Draganits, E., and Timar, G.: Neotectonic control on river sinuosity at the western margin of the Little Hungarian Plain, Geomorphology, 122, 231-243, doi:10.1016/j.geomorph.2009.06.028, 2010.

Ziliani, L. and Surian, N.: Evolutionary trajectory of channel morphology and controlling factors in a large gravel-bed river, Geomorphology, 173, 104-117, doi:10.1016/j.geomorph.2012.06.001, 2012.

Zimova, R., Pestak, J., and Veverka, B.: Historical military mapping of the Czech lands - Cartographic Analysis, International Conference on Cartography and GIS, Borovets, Bulgaria, 1-7, 2006.

Zlinszky, A. and Molnár, G.: The first bathymetric maps of Lake Balaton, Hungary, European Geosciences Union General Assembly 2008, Vienna, 2008.

Zlinszky, A., Székely, B., and Clement, A.: Comparing sediment load and deposit thickness values in the eastern embayment of shallow Lake Balaton, Hungary, European Geosciences Union General Assembly 2008, Wien, Austria, 13-18 April 2008, SRefID: 1607-7962/gra/EGU2008-A-06101, 2008.

Zlinszky, A. and Molnár, G.: Georeferencing the first bathymetric maps of Lake Balaton, Hungary, Acta Geod. Geophys. Hu., 44, 79-94, doi:10.1556/AGeod.44.2009.1.8, 2009.

Zlinszky, A.: Measuring historic water levels of Lake Balaton and the neighbouring valleys, Acta Geod. Geophys. Hu., 45, 39-47, doi:10.1556/AGeod.45.2010.1.7, 2010.

Zólyomi, B., and Nagy, L.: A Balaton múltja a pollensztratigráfiai vizsgálatok tükrében, in: 100 éves a Balatonkutatás, XXXII. Hidrobiológus napok, Tihany, 1991, 25-32, 1992. 